\title{
Recent studies of the copper-molybdenum antagonism
}

\author{
By N. F. SuTTLE, Moredun Research Institute, Edinburgh EHI 7 7fH
}

The biological antagonism between copper and molybdenum was discovered when cattle grazing pastures high in Mo were found to develop a syndrome characterized by diarrhoea, growth retardation, anaemia and achromotrichia, which could be prevented by administering $\mathrm{Cu}$. This syndrome was subsequently reproduced in non-ruminants, but further studies revealed important differences in the nature of the antagonism. In ruminants, dietary sulphate potentiated a $\mathrm{Cu}-\mathrm{Mo}$ antagonism which decreased tissue $\mathrm{Cu}$ concentrations but, in non-ruminants, sulphate alleviated an antagonism, which increased tissue $\mathrm{Cu}$ (Dick, 1956; Miller \& Engel, I960; Underwood, 1962). The above studies generally involved Mo concentrations far in excess of those found in natural foodstuffs and the complex interrelationships were, therefore, considered to be of largely academic interest. Recent studies have, however, revealed evidence of a more widespread nutritional significance of the $\mathrm{Cu}-\mathrm{Mo}$ antagonism for ruminants and non-ruminants and explanations for the contrasting responses of the two groups.

\section{Significance of the rumen}

The gut plays a vital part in the Cu-Mo-sulphur interaction in ruminants, since the effect of dietary $\mathrm{Mo}$ on $\mathrm{Cu}$ status is considerably reduced if the gut is bypassed by supplying $\mathrm{Cu}$ either by subcutaneous injection (Clawson, Lesperance, Bohman \& Layhee, 1972; Suttle \& Field, 1974) or by intravenous infusion (Suttle, $\mathrm{I} 974 \mathrm{~b}$ ). Since the effect is also reduced by giving Mo by abomasal infusion (Suttle, unpublished results), the important locus within the gut would appear to be the rumen.

The development of a functional rumen has considerable effects on the metabolism of each element in the interaction. The availability of both $\mathrm{Cu}$ and Mo falls after weaning and the involvement of the rumen has been established by comparing the availability of ${ }^{89} \mathrm{Mo}$ and ${ }^{64} \mathrm{Cu}$ given via the abomasum or the rumen. The availability of Mo to calves increases from 30 to $62 \%$ (Miller, Moss, Bell \& Sneed, 1972) and that of $\mathrm{Cu}$ to lambs from 3.7 to $21 \cdot 4 \%$ (Suttle, unpublished results) when the rumen is by-passed. The metabolism of $S$ is dominated by sulpholytic bacteria in the rumen, which degrade both inorganic and organic $\mathbf{S}$ to sulphide; this is then extensively absorbed across the ruminal epithelium (Moir, 1970).

Dietary supplements of Mo and $\mathrm{S}$ have the following effects on $\mathrm{Cu}$ and Mo metabolism in sheep, which in many ways confirm the earlier findings of Dick (1956). Mo alone ( $4 \mathrm{mg} / \mathrm{kg}$ ) increases plasma Mo by $\mathrm{I}-2 \mathrm{mg} / \mathrm{l}$ but has no effect on the 
availability of dietary $\mathrm{Cu}$, while $\mathrm{S}$ alone $(3 \mathrm{~g} / \mathrm{kg})$ slightly reduces $\mathrm{Cu}$ availability. Together, the two elements produce a $50 \%$ reduction in $\mathrm{Cu}$ availability with no elevation of plasma Mo (Suttle, I974b).

Any hypothesis for the $\mathrm{Cu}-\mathrm{Mo}-\mathrm{S}$ interaction occurring in the rumen should, therefore, account for the fact that dietary $\mathrm{S}$ renders both $\mathrm{Cu}$ and Mo unavailable whereas dietary Mo lowers $\mathrm{Cu}$ availability only in the presence of dietary $\mathrm{S}$. These facts can be explained by the formation of an unavailable complex containing each of the three elements. In vitro studies have shown that the passage of $\mathrm{H}_{2} \mathrm{~S}$ through an ammoniacal solution containing $\mathrm{MoO}_{4}{ }^{2-}$ leads to the formation of thiomolybdate $\left(\mathrm{MoS}_{4}{ }^{2-}\right.$; Tridot \& Bernard, 1962). In the sulphide-rich environment of the rumen, it is conceivable that $\mathrm{Cu}$ enters the unavailable form of cupric thiomolybdate when the diet is rich in Mo.

Consistent with the thiomolybdate hypothesis are findings that organic and inorganic $\mathrm{S}$, which are both degraded to $\mathrm{S}^{2-}$, are equally effective in enabling Mo to lower the availability of $\mathrm{Cu}$ (Suttle, $\mathrm{I} 974 b$ ) and in reducing Mo concentrations in plasma or urine (Cook, Lesperance, Bohman \& Jensen, I966; Suttle, unpublished results). In the past it has been assumed from the work of Dick (1956) that only inorganic $\mathrm{S}$ interacted with $\mathrm{Cu}$ and $\mathrm{Mo}$.

A quite different antagonism has been reported in sheep given diets containing urea and sulphate as the only sources of $\mathrm{N}$ and $\mathrm{S}$, in which Mo alleviates the anaemia that develops on a low-Cu diet (Huisingh, Gomez \& Matrone, 1973). The interaction was explained by the inhibition by Mo of sulphide-forming microbes; these contain a new species of Desulphovibrio with an enhanced capacity for $\mathrm{S}^{2-}$ formation (Huisingh \& Matrone, I972; Huisingh, McNeill \& Matrone, r973).

\section{The contrasting role of sulphate}

The ability of dietary sulphate to alleviate molybdenosis in the non-ruminant is probably attributable to a direct antagonism between $\mathrm{SO}_{4}{ }^{2-}$ and $\mathrm{MoO}_{4}{ }^{2-}$ in the gut. Huisingh, Gomez et al. (1973) found that $\mathrm{SO}_{4}{ }^{2-}$ suppressed the uptake of $\mathrm{MoO}_{4}{ }^{2-}$ from chick intestine and postulated that these two tetrahedral anions of similar electronic configuration compete for a common absorptive pathway. Although a similar antagonism could affect the tissue uptake and renal tubular reabsorption of $\mathrm{MoO}_{4}{ }^{2-}$, leading to enhanced $\mathrm{MoO}_{4}{ }^{2-}$ excretion, the primary site of interaction may well lie in the gut, since dietary $S$ reduces rather than increases the urinary excretion of Mo (Kinnamon, 1966; Amon, Scheler \& Peters, 1967).

In ruminants the $\mathrm{SO}_{4}{ }^{2--}-\mathrm{MoO}_{4}{ }^{2-}$ antagonism is forestalled by the fact that most of the $\mathrm{SO}_{4}{ }^{2-}$ is removed as sulphide from the rumen, while Mo enters unavailable forms. There are, however, conditions in which a postabsorptive antagonism can operate, such as those which led Dick (1956) to suggest that $\mathrm{SO}_{4}{ }^{2-}$ impeded the transport of $\mathrm{MoO}_{4}{ }^{2-}$ across biological membranes. He found that the addition of $\mathrm{SO}_{4}{ }^{2-}$ to the diet of ewes, previously given Mo, flushed Mo from the body.

An observation that dietary $\mathrm{SO}_{4}{ }^{2-}(27 \mathrm{~g} / \mathrm{kg})$ exacerbated molybdenosis in rats previously depleted of $\mathrm{Cu}$, but alleviated molybdenosis in the $\mathrm{Cu}$-replete rat, led 
Gray \& Daniel ( 1964 ) to attribute the contrasting role of $\mathrm{SO}_{4}{ }^{2-}$ to differences in $\mathrm{Cu}$ status. There is, however, no evidence that ruminants and non-ruminants differ in this respect in the absence of dietary Mo. Furthermore, Cu status does not influence the response of the ruminant to Mo since a combined supplement of $\mathrm{Mo}$ and $\mathrm{SO}_{4}{ }^{2-}$ is as effective in treating or preventing $\mathrm{Cu}$ toxicosis (Ross, 1966; Hogan, Money \& Blayney, I968; Kline, Hays \& Cromwell, I97I) as it is in inducing $\mathrm{Cu}$ deficiency in sheep (Fell, Williams \& Mills, I96I; Suttle \& Field, 1969). It is conceivable that Gray \& Daniel (1964) were dealing with differences in Mo status rather than $\mathrm{Cu}$ status, since their $\mathrm{Cu}$-replete rats were given eight times more $\mathrm{Mo}$ than their depleted rats $(100 \mathrm{mg} / \mathrm{kg})$ and the depression of growth was no longer counteracted by dietary $\mathrm{Cu}(300 \mathrm{mg} / \mathrm{kg})$.

\section{Importance of dietary Mo concentration}

A further factor contributing to the contrasting nature of the $\mathrm{Cu}-\mathrm{Mo}$ antagonism in ruminants and non-ruminants has been the use of different $\mathrm{Cu}$ and Mo concentrations. Experimental and field studies with ruminants have involved Mo concentrations of $7-100 \mathrm{mg} / \mathrm{kg}$ and $\mathrm{Cu}:$ Mo ratios generally $<\mathrm{I}: 5$, whereas those with non-ruminants have involved concentrations of $100-800 \mathrm{mg} \mathrm{Mo} / \mathrm{kg}$ and $\mathrm{Cu}:$ Mo ratios of the order of $\mathrm{I}: 50$. Furthermore, the higher availability of Mo to the non-ruminant means that a given dietary Mo concentration will be the more able to induce a systemic interaction.

In the guinea-pig, the dietary concentration of Mo has a profound effect upon the nature of the $\mathrm{Cu}-\mathrm{Mo}$ antagonism. At concentrations below $100 \mathrm{mg} / \mathrm{kg}$, Mo decreases the $\mathrm{Cu}$ status of the animal, but the extent of $\mathrm{Cu}$ depletion is proportional to the $\log$ of dietary Mo concentration (Suttle, 1974a). At concentrations above $100 \mathrm{mg} / \mathrm{kg}$, however, the more familiar response, namely increased tissue $\mathrm{Cu}$ concentrations accompanied by clinical $\mathrm{Cu}$ deficiency, pertains (Arthur, 1965).

It is possible that, at low Mo concentrations, the primary site of interaction is in the gut, resulting in a decreased uptake of $\mathrm{Cu}$, whereas at high Mo concentrations, high levels of Mo in the bloodstream and tissues favour the formation of inorganic and organic $\mathrm{Cu}-\mathrm{Mo}$ complexes, which accumulate in the tissues.

\section{Biological significance of $\mathrm{Cu}-\mathrm{Mo}$ complexes}

A new mechanism for the $\mathrm{Cu}-\mathrm{Mo}$ antagonism has been advanced, involving the complexing of $\mathrm{Cu}$ with $\mathrm{Mo}$ in a compound resembling cupric molybdate. The $\mathrm{Cu}-\mathrm{Mo}$ complex forms in vitro at neutral $\mathrm{pH}$ in solutions containing $\mathrm{Cu}^{2+}$ and $\mathrm{MoO}_{4}{ }^{2-}$ (Dowdy \& Matrone, I968a; Dowdy, Kunz \& Sauberlich, 1969). Given in the milk diet of pigs, it is absorbed but remains unavailable for caeruloplasmin synthesis (Dowdy \& Matrone, 1968a). Given intravenously to the sheep, its $\mathrm{Cu}$ and Mo appear to be excreted in such a way that little or none becomes available to the tissues (Dowdy \& Matrone, $1968 b$ ).

The biological significance of the hypothesis depends on (a) conditions being favourable to the formation and continued existence of the complex in the gut or in 
the tissues and (b) known facts concerning the $\mathrm{Cu}-\mathrm{Mo}$ antagonism being consistent with complex formation. In vivo formation of the complex has yet to be proven. Mills \& Mitchell (197 I) have reported that in Mo-supplemented rats, $\mathrm{Cu}$ and Mo accumulate in the connective tissue and nuclear components of liver in the ratio found in $\mathrm{CuMoO}_{4}$; however, this proportionality has not been observed in the whole liver of animals given the preformed complex (Dowdy \& Matrone, I968a).

The $\mathrm{Cu}-\mathrm{Mo}$ complex dissociates below $\mathrm{pH}_{3}$ and some breakdown of the complex is likely at the $\mathrm{pH}$ encountered in the abomasum or stomach. The fact that $\mathrm{Cu}$ from $\mathrm{CuMoO}_{4}$ is only marginally less available for caeruloplasmin synthesis than that from $\mathrm{CuSO}_{4}$ in the weaned rat (Dowdy et al. 1969) is suggestive of breakdown of the complex. In testing the biological availability of $\mathrm{Cu}$ in $\mathrm{CuMoO}_{4}$, some groups were given $\mathrm{Cu}$ and Mo separately in amounts equivalent to those present in the complex (Dowdy \& Matrone, I968a; Dowdy et al. 1969); Cu availability was largely unaffected, however, indicating little or no in vivo formation of the complex.

The combined evidence, therefore, suggests that it is premature to attach biological significance to the role of $\mathrm{CuMoO}_{4}$ in the $\mathrm{Cu}-\mathrm{Mo}$ antagonism. On the other hand, the increase in tissue $\mathrm{Cu}$ concentrations in molybdenosis suggests that $\mathrm{Cu}$ has accumulated in a biologically unavailable form and it is possible that organic complexes containing $\mathrm{Cu}$ and $\mathrm{Mo}$ are of some significance. Studies of the distribution of $\mathrm{Cu}$ in the plasma of Mo-supplemented sheep and guinea-pigs have shown that caeruloplasmin and direct-reacting $\mathrm{Cu}$ do not account for all of the $\mathrm{Cu}$ (Suttle \& Field, 1968; Smith, Field \& Suttle, 1968; Suttle, 1974a). The 'residual Cu' fraction is precipitated by trichloroacetic acid and contains both Mo (Smith \& Wright, 1973) and protein (B. S. W. Smith \& H. Wright, unpublished results). The origin and metabolic significance of this fraction has yet to be established, however.

\section{Additional systemic interactions}

It is difficult to identify systemic sites for the $\mathrm{Cu}-\mathrm{Mo}-\mathrm{S}$ interaction because interactions located in the gut effect changes at the tissue level. Several workers have reported a decrease in caeruloplasmin synthesis in Mo-supplemented animals (Gaballah, Abood, Kapsalis \& Sturdivant, 1965; Smith et al. 1968; Marcilese, Ammerman, Valsecchi, Dunavant \& Davis, I969) which could obviously result from a decrease in the supply of absorbed $\mathrm{Cu}$ rather than a systemic effect on caeruloplasmin synthesis.

Mo supplementation increases the direct-reacting fraction of the plasma $\mathrm{Cu}$ (Suttle \& Field, 1968; Marcilese et al. 1969) and this effect has been shown to be a true systemic effect of Mo, occurring in sheep in which the predominant supply of $\mathrm{Cu}$ came from a subcutaneous injection (Suttle \& Field, 1974). The effect is dependent on dietary Mo concentration (Suttle, r $974 a$ ) and may reflect an impaired uptake of absorbed $\mathrm{Cu}$ by the tissues or a direct effect of Mo on the capacity of plasma proteins to bind $\mathrm{Cu}$.

The urinary excretion of $\mathrm{Cu}$ is increased by Mo in both ruminants (Ryś, Kuklewicz \& Sokół, 1963; Smith et al. 1968; Marcilese, Ammerman, Valsecchi, Dunavant 
$\&$ Davis, 1970 ) and non-ruminants (Compère, Burny, Francois, Riza \& Vanutrecht, 1965), possibly as a consequence of the increase in direct-reacting $\mathrm{Cu}$ in plasma. Alternatively, the additional $\mathrm{Cu}$ may be in the form of 'foreign' $\mathrm{Cu}-\mathrm{Mo}$ complexes, originating in the gut or tissues, which the kidney tries to excrete. The accumulation of $\mathrm{Cu}$ in the kidneys of Mo-supplemented sheep (Suttle \& Field, ig68; Marcilese et al. 1970) supports the latter postulate. The significance of enhanced urinary $\mathrm{Cu}$ excretion in contributing to the depletion of $\mathrm{Cu}$ reserves probably increases as Mo intake increases.

An early explanation offered for the Cu-Mo-S interaction involved the inhibition of liver sulphide oxidase by $\mathrm{Mo}$ and the subsequent precipitation of insoluble CuS (Mills, Monty, Ichihara \& Pearson, I958). However, Siegel \& Monty (196I) found that this effect resulted indirectly from the depression of appetite in the molybdenotic rat. Rish (1970) has recently claimed that liver sulphide oxidase is inhibited and that sulphides accumulate in both brain and liver of sheep affected by Moinduced $\mathrm{Cu}$ deficiency. In view of the importance of $\mathrm{S}^{2-}$ metabolism in the ruminant, this possible systemic antagonism warrants further study.

\section{Nutritional significance of the $\mathrm{Cu}$-Mo antagonism}

The nutritional significance of the $\mathrm{Cu}-\mathrm{Mo}$ antagonism is determined by the natural variation in $\mathrm{Cu}, \mathrm{Mo}$ and $\mathrm{S}$ concentrations in the diet. If the respective ranges embrace those concentrations found to influence $\mathrm{Cu}$ metabolism experimentally, then the antagonism assumes widespread nutritional significance.

As far as the ruminant is concerned, Mo concentrations in herbage commonly range from 0.5 to $4 \mathrm{mg} / \mathrm{kg}$ (Whitehead, 1966; Miltimore \& Mason, 197 $\mathrm{x}$ ) and $\mathrm{S}$ concentrations from I to $4 \mathrm{~g} / \mathrm{kg}$ (Whitehead, 1966). The addition of $4 \mathrm{mg} \mathrm{Mo} / \mathrm{kg}$ to the diet of sheep at the higher level of $\mathrm{S}$ has been estimated to reduce the availability of dietary $\mathrm{Cu}$ by $50 \%$, and an increase in $\mathrm{S}$ concentration from 2 to $3 \mathrm{~g} / \mathrm{kg}$ at an intermediate Mo concentration has a similar effect (Suttle, I974b). It would, therefore, appear that the $\mathrm{Cu}-\mathrm{Mo}$ antagonism affects sheep and probably cattle over a far wider range of pasture conditions than has hitherto been believed (Allcroft \& Lewis, 1957; Hartmans, 1970). These results also lend support to the thesis of Todd (1972) that the relatively low concentrations of $\mathrm{Mo}$ and $\mathrm{S}$ in cereals contribute to the high risk of $\mathrm{Cu}$ toxicity in sheep given concentrated foodstuffs; serious consideration should be given to the routine use of small Mo supplements in such foodstuffs. The most useful formula for predicting the effects of dietary Mo and S on the availability of $\mathrm{Cu}$ in herbage and concentrates may be the product log (Mo concentration) $\times \log$ ( $\mathrm{S}$ concentration).

In non-ruminants, the practical problem may be one of induced Mo deficiency rather than excess. Experimental Mo deficiency in the chick results in anaemia (Anders \& Hill, 1970) and a link between Mo and Fe metabolism is provided by the Mo-containing enzyme xanthine oxidase ( $E C$ 1.2.3.2), which facilitates the reduction of ferritin-bound Fe. It has been known for some time that some anaemias in man respond more to Mo plus Fe than to Fe alone, and Seelig (1972) has suggested that since the human diet contains an excess of $\mathrm{Cu}$ relative to $\mathrm{Mo}$, formation of $33(3) 8$ 
insoluble or unavailable $\mathrm{Cu}-\mathrm{Mo}$ complexes would prejudice Mo metabolism before $\mathrm{Cu}$ metabolism. The foregoing discussion, however, indicates that $\mathrm{SO}_{4}{ }^{2-}$ is probably a more effective and biologically important antagonist of $\mathrm{Mo}$ than $\mathrm{Cu}$ is, and its role in inducing Mo deficiency warrants investigation.

In some areas where industrial Mo pollution is a problem, Mo intakes may be sufficiently high to interfere with $\mathrm{Cu}$ metabolism in man. Mo concentrations as low as $4^{-10} \mathrm{mg} / \mathrm{kg}$ have been found to reduce the $\mathrm{Cu}$ status of non-ruminants (Gray \& Daniel, 1964; Suttle, 1974a) and Warren (1972) has recorded Mo concentrations as high as $10-30 \mathrm{mg} / \mathrm{kg}$ dry matter in a wide range of vegetables in some localities. It seems unlikely, however, that Mo pollution alone would be so severe as to induce clinical $\mathrm{Cu}$ deficiency in man. It would nevertheless be worthwhile to study the therapeutic application of the $\mathrm{Cu}-\mathrm{Mo}$ antagonism in the treatment of Wilson's disease in man, as a safer means of reducing the $\mathrm{Cu}$ status of the patient than by drug therapy.

\section{Conclusions}

The contrasting responses of ruminants and non-ruminants to the $\mathrm{Cu}-\mathrm{Mo}$ antagonism are probably related to the influence of the rumen and to the Mo injury to which the species have been subjected. At the relatively low $\mathrm{Mo:} \mathrm{Cu}$ ratios prevailing in the ruminant diet, the primary antagonism probably occurs in the rumen through the involvement of sulphide-generating bacteria and the consequent formation of unavailable compounds such as cupric thiomolybdate. In both ruminants and non-ruminants, the importance of systemic sites of interaction probably increases as the $\mathrm{Mo}: \mathrm{Cu}$ ratio rises, and $\mathrm{SO}_{4}{ }^{2-}$ uptake becomes beneficial to both in accelerating the excretion of Mo. The $\mathrm{Cu}-\mathrm{Mo}-\mathrm{S}$ antagonism is probably widely involved in the aetiology of both $\mathrm{Cu}$ deficiency and $\mathrm{Cu}$ toxicity in sheep and may induce Mo deficiency in man. It may be usefully applied in the treatment and prevention of $\mathrm{Cu}$ toxicity in both sheep and man.

\section{REFERENCES}

Allcroft, R. \& Lewis, G. (1957). F. Sci. Fd Agric. 8, S96.

Amon, I., Scheler, W. \& Peters, R. (1967). Acta biol. med. germ. 19, 985.

Anders, E. \& Hill, C. (1970). Fedn Proc. Fedn Am. Socs exp. Biol. 29, 766.

Arthur, D. (1965). F. Nutr. 87,69.

Clawson, W. J., Lesperance, A. L., Bohman, V. R. \& Layhee, D. C. (1972). 7. Anim. Sci. 34, 516.

Compère, R., Burny, A, Francois, E., Riza, A. \& Vanutrecht, S. (1965). Bull. Inst. agron. Stns Rech. Gembloux 32, 17 I.

Cook, G. A., Lesperance, A. L., Bohman, V. R. \& Jensen, E. H. (rg66). 7. Anim. Sci. 25, 96.

Dick, A. T. (1956). In Inorganic Nitrogen Metabolism p. 445 [W. D. McElroy and B. Glass, editors]. Baltimore, Maryland: Johns Hopkins Press.

Dowdy, R. P., Kunz, G. A. \& Sauberlich, H. E. (r969). F. Nutr. 99, 49 I.

Dowdy, R. P. \& Matrone, G. (r968a). F. Nutr. 95, 191.

Dowdy, R. P. \& Matrone, G. (1 $968 b$ ). F. Nutr. 95, 197.

Fell, B. F., Williams, R. B. \& Mills, C. F. (I96r). Proc. Nutr. Soc. 20, xxvii.

Gaballah, S., Abood, L. G., Kapsalis, A. \& Sturdivant, D. (r965). Proc. Soc. exp. Biol. Med. Ir9, 625.

Gray, L. F. \& Daniel, L. J. (1964). F. Nutr. 84, 3 I.

Hartmans, J. (1970). In Trace Element Metabolism in Animals p. 44 I [C. F. Mills, editor]. Edinburgh: E. \& S. Livingstone.

Hogan, K. G., Money, D. F. L. \& Blayney, A. (1968). N.Z. भl agric. Res. rr, 435.

Huisingh, J., Gomez, G. G. \& Matrone, G. (1973). Fedn Proc. Fedn Am. Socs exp. Biol. 32, I921. 
Huisingh, J., McNeill, J. J. \& Matrone, G. (1973). Fedn Proc. Fedn Am. Socs exp. Biol. 32, 9oo.

Huisingh, J. \& Matrone, G. (1972). Proc. Soc. exp. Biol. Med. 139, 5 I8.

Kinnamon, K. E. (1966). F. Nutr. 89, 365.

Kline, R. D., Hays, V. W. \& Cromwell, G. I. (1971). 7. Anim. Sci. 33, 771.

Marcilese, N. A., Ammerman, C. B., Valsecchi, R. M., Dunavant, B. G. \& Davis, G. K. (Ig69). F. Nutr. 99, 177 .

Marcilese, N. A., Ammerman, C. B., Valsecchi, R. M., Dunavant, B. G. \& Davis, G. K. (1970). $\mathfrak{F}$. Nutr. Ioo, ז399.

Miller, R. F. \& Engel, R. W. (1960). Fedn Proc. Fedn Am. Socs exp. Biol. r9, 666.

Miller, J. K., Moss, B. R., Bell, M. C. \& Sneed, N. (1972). F. Anim. Sci. 34, 846 .

Mills, C. F. \& Mitchell, R. L. (I97r). Br. F. Nutr. 26, I 1 7.

Mills, C. F., Monty, K. J., Ichihara, A. \& Pearson, P. B. (I958). F. Nutr. 65, 129.

Miltimore, L. E. \& Mason, J. L. (197I). Can. F. Anim. Sci. 5x, 193.

Moir, R. J. (1970). Symposium on Sulphur in Nutrition p. $6_{5}$. Connecticut: Avi Publishing Co.

Rish, M. A. (I970). In Trace Element Metabolism in Animals [C. F. Mills, editor]. Edinburgh: E. \& S. Livingstone.

Ross, D. B. (1966). Br. vet. Y. 122, 279 .

Ryś, R. M., Kuklewicz, M. \& Sokół, J. (1963). Roczn. Nauk roln. Ser. B. 83, 145.

Seelig, M. S. (1972). Am. F. clin. Nutr. 25, 1022.

Siegel, L. M. \& Monty, K. J. (r96r). \%. Nutr. 74, I67.

Smith, B. S. W., Field, A. C. \& Suttle, N. F. (ig68). F. comp. Path. Ther. 78, 449.

Smith, B. S. W. \& Wright, H. (1973). Proc. Nutr. Soc. 32, 25 A.

Suttle, N. F. (I974a). Proc. 8th a. Conf. Trace Substances in Environmental Health, Columbia, Missouri p. 245 .

Suttle, N. F. (1974b). In Trace Element Metabolism in Animals [W. G. Hoekstra, J. W. Suttie, H. E. Ganther and W. Mertz, editors]. Baltimore, Maryland: University Park Press.

Suttle, N. F. \& Field, A. C. (1968). F. comp. Path. Ther. 78, 35 I.

Suttle, N. F. \& Field, A. C. (1969). F. comp. Path. Ther. 79, 453.

Suttle, N. F. \& Field, A. C. (1974). Vet. Rec. 95 , I65.

'Todd, J. R. (1972). F. agric. Sci., Camb. 79, r91.

Tridot, G. \& Bernard, J. C. (I962). Acta chim. hung. 34, 179.

Underwood, E. J. (1962). Trace Elements in Human and Animal Nutrition p. 48. New York: Academic Press.

Warren, H. V. (1972). fl R. Coll. gen. Pract. 22, 56.

Whitehead, D. C. (1966). Nutrient Minerals in Grassland Herbage p. 42. Hurley: Commonwealth Bureau of Pastures \& Field Crops. 